\title{
IDEGEN NYELVEK ELSAJÁTÍTÁSA KORA GYERMEKKORBAN
}

\section{TAKÁCS GERDA}

\author{
az Apor Vilmos Katolikus Főiskola \\ föiskolai tanársegédje \\ takacs.gerda@avkf.hu
}

Kovács Judit „A gyermek és az idegen nyelv” címü könyve 2009 decemberében jelent meg az Eötvös József Könyvkiadó gondozásában. A szerző az ELTE Tanítóés Óvóképző Karának docense. Fő kutatási területei a korai idegennyelv-oktatás és a kéttannyelvű oktatás. Ez a munkája e kettőt ötvözi abból kiindulva, hogy Magyarországon általánosan elterjedt tévhit, hogy az idegen nyelvek tanulását 10 éves kor előtt nem érdemes, sőt káros elkezdeni. Abból indul ki, hogy az új évezred első éveire a nyelvoktatás a pedagógiai szakma legdinamikusabban fejlődő ágává vált. A tíz éven aluliak nyelvoktatásával foglalkozó magyar nyelvủ irodalom bővült ugyan, de eleddig még nem született olyan összefoglaló munka, mely ezen és az angol nyelven a témával foglalkozó irodalmakat magyar nyelven bemutatná. Ugyanakkor a demográfiai okoknak (is) köszönhetően versenyfutás kezdődött a gyerekekért, az iskolák, mint szolgáltatók jelennek mely, melyek kínálatát alapvetően meghatározzák a szülői igények. Az egyik legfőbb kínálati tényező az idegen nyelv, mert a szülők értékrendjében az idegen nyelv különleges árucikknek minősül, melyhez minél előbb és minden áron célszerü hozzájutni.

Az első három fejezet, más-más aspektusból, a korai nyelvfejlesztést megalapozó elméleti hátteret mutatja be. Az első megismerteti az olvasót a „kritikus periódus elmélettel", mely szerint a gyermeki fejlödésben a pubertás kezdete után elkezdett nyelvtanulás az agyban eljátszódó fiziológiai változások miatt nem lehet olyan sikeres, mint ezen életkor elött. A kisgyermeknek ugyanis több idegsejtje van, mint a felnőttnek, ezért érzékenyebben reagál a hangokra, pontosabban meg tudja különböztetni és reprodukálni ezeket a hangokat. A későbbi életkorban sok idegsejt közti kapcsolat felbomlik. Ráadásul a gyermek pubertás korban tanulási stratégiát vált, már nem globálisan, hanem elemző módon, mindig csak egy nyelvi szintre koncentrálva tanulja az idegen nyelvet. Ezért állíthatjuk, hogy a korai kezdés potenciális előnnyel jár elsősorban a hangrendszer tekintetében, hogy hosszabb idő áll rendelkezésre a nyelvi tudatosság és a nyelvtanulási tapasztalat szerzése szempontjából, hogy módot nyújt a kooperatív technikák alkalmazására más országok tanulóival, például projektekben való együttmüködésben, hogy a nyelvtanulást később kezdőknek kevesebb esélyük van a célnyelvet anyanyelvként beszélők szintjének az elérésére. Ezért is müködnek több európai országban idegen nyelvi óvodai prog- 
ramok. Sikerük kulcsa a hosszú távú tervezés, a kontinuitás, vagyis a program folytatásának biztosítása későbbi életkorban, a jól képzett, kiváló kiejtéssel és intonációval rendelkező tanárok/óvónők, a tantárgyközi és interkulturális tevékenységbe ágyazott feladatok, a program financiális hátterének biztosítása. A korai idegen nyelvi programok közül különösen a tantárgyközi, a mesealapú, illetve a tartalomalapú oktatás mutatkozott sikeresnek. Másik aspektusa a korai idegen nyelvtanulásnak a kognitív terület. Az elmúlt 50 év kutatási eredményeivel alátámasztható, hogy az idegen nyelv tanulása számos területen pozitívan hat a kognitív készségekre. Sikeres korai idegennyelv-oktatás csak abban az esetben valósulhat meg, ha az az általános fejlesztés része, és nem kizárólagos nyelvi cél. A korai nyelvi programok csak akkor sikeresek, ha a célok holisztikusak, vagyis a gyermek egész személyiségét fejlesztik, az elsajátítandó ismeretek és készségek között átjárhatóság van, melyet az osztálytanító vagy az óvodapedagógus biztosít. E szerint a felfogás szerint az idegen nyelv tanulásának célja az általános nevelési célokon belül hozzájárulás a fogalmi gondolkodás fejlesztéséhez, a készség- és képességfejlesztéshez, a nyelvhez füződő pozitív attitüd kialakítása, és a konkrét nyelvi haszon megvalósulása. Lehetőség nyílik új tanulási stratégiák megszerzésére is. A nyelvtanulás hozadéka ebben az esetben az önbizalom, énkép fejlődése, illetve az életkori sajátosságoknak megfelelő, autentikus nyelvi és kulturális tananyagokkal való megismerkedés.

A második fejezet megismerteti az olvasót a korai idegennyelv-oktatás gyermekpszichológiai és alkalmazott nyelvészeti alapjaival. Rávilágít, hogy kora gyermekkorban szorosabb az összefüggés az anyanyelv és az idegen nyelv között, mert a gyermek az anyanyelv analógiájára sajátítja el az idegen nyelvet. A legfontosabb szempont, hogy a nyelvelsajátítás a gyermek számára értelmes kontextusban történjék. A továbbiakban a szerző ismerteti az empirista, a nativista, a kognitív és szociokognitív nyelvelsajátítási elméleteket, majd a gyermeki gondolkodás és tanulás sajátosságait. Négy pontban foglalhatók össze a gyermeki gondolkodás jellemzői: (1) nem fogalmi jellegü, elsősorban cselekvésekhez kötődik, (2) másokkal való interakcióban fejlődik, (3) alapvetően az érzékszervekkel való megismerésre támaszkodik, (4) struktúrákhoz, ismert szituációkhoz vonzódik. A korai kéttannyelvüség a sikeres korai nyelvfejlesztés alapja, ha a tanítás kellö intenzitású, a tanár magas fokú nyelvi kompetenciákkal rendelkezik, és a tananyagok a korosztály igényeihez maximálisan alkalmazkodnak. A magyar közoktatásban ezek a feltételek legjobban a két tanítási nyelvü és a tartalomalapú programokban valósulnak meg. Ezek alapján a tanári szerepek is jelentősen módosulnak az idegennyelv-elsajátítás esetén is. A tanár nem lehet pusztán ismeretközlő személy, hanem tanulást megkönnyítö, tanácsadó, partner, koordinátor, monitor szerepeket lát el, s akinek munkája tanulóközpontú kell, hogy legyen. A tanár munkáját áthatja a reflektivitás, munkájának tartalma nem csak a tervezés és a tényleges megvalósítás, hanem a megtartott óráról való professzionális gondolkodás is. A tanári tudás legfontosabb elemei, melyek hozzájárulnak a korai nyelvelsajátítás sikerességéhez az alábbiak: 
(1) a fiatal nyelvtanuló halljon minél több értelmes nyelvi elemet, s maga is aktív részese legyen a kommunikációnak, (2) a gyermek akkor kommunikál hatékonyan, ha közben alkalma nyílik cselekvések végzésére, (3) a gyermek akkor érez hajlandóságot a kommunikációra, ha van választása abban, hogy mit mondjon és van is mondanivalója! Tehát funkcionálisan használja a nyelvet, (4) nagyon fontos része a tanulásnak a nem verbális elemek használata, (5) a játék a gátlás, szorongás nélküli gyakorlás alapját adja, (6) az elismerés különbözö formáinak, a bátorításnak állandóan jelen kell lenni a tanulási folyamatban.

Ezután a szerző két módszertani modellt, a klasszikus és a jó általános iskolai gyakorlat modelljét hasonlítja össze. Bemutatja a tananyagközpontú szervezést, a tanulás ideális helyszínét (nem rögzített asztalok, székek, vastag szőnyeg), a legfontosabb óraszervezési kérdéseket (rutinelemek, órakezdés, -befejezés, kiszámolók, ismétlődés, biztonságot adó tényezők, dekoráció), eszközigényességet, munkaformákat. A korai nyelvfejlesztés fő módszerei a tevékenység közbeni tanulás, a másokkal való interakcióban való tanulás, az érzékszervek útján történő tanulás, a valós kommunikációs szituációkban történő témaközpontú tanulás. A korai szakaszban a négy alapkészség, vagyis a hallás utáni értés, a beszéd, az olvasás- és íráskészség közül a két első fejlesztése kiemelt fontosságú. Az anyanyelvhez hasonlóan az idegen nyelv elsősorban szóbeli úton jut el a gyermekekhez, ez jelenti a nyelvi fejlesztés specifikumát. A szóbeli készségek fejlesztését szolgálja a célnyelvi óravezetés is, amely a tanár részéről magas fokú nyelvi felkészültséget kíván. A korai szóbeli készségfejlesztés kétfázisú folyamat, a kezdeti („csendes”) szakaszban a gyermek befogadja, a második szakaszban pedig önállóan is produkálja a nyelvet. A szerző részletesen bemutatja a csendes szakasz tevékenységi formáit a „hallgasd meg és csináld” gyakorlatoktól kezdve a „Simon says” gyakorlatokon át a cselekvéssel válaszoló feladatokig. Külön fejezetet szentel a beszédprodukció első lépéseinek, akár csak a magasabb szintủ fejlesztéseknek. Gyakorlati példákkal támasztja alá a következetes kódhasználat jelentőségét. Bár elsődleges szempont a célnyelvi óravezetés, a körülmények nagyban befolyásolják ennek következetes betartását. A könyvben megismerkedhet az olvasó olyan helyzetekkel, mikor érdemes felülírni a célnyelvi óravezetés kívánalmát (a gyermeket meg kell nyugtatni, együttérzést kell kifejezni, időt akar a pedagógus megtakarítani). A tanulók kódváltása viszont másképp értelmezendő, hisz ha a gyermek csak anyanyelvén tud válaszolni egy célnyelven feltett kérdésre, az is tükrözi a megértést.

A korai nyelvelsajátítás ellen érvelők egyik fó érve az írásbeliséggel kapcsolatos. A szerző bebizonyítja, hogy az írás-olvasást is lehet a gyermek természetes tanulási módján, érzékelés útján és tevékenységbe ágyazottan tanítani. Az írásbeliség formáinak bevezetését mindig meg kell, hogy előzze egy szóbeli bevezető szakasz, amely a „nyelvi fürdő” része. A magyarországi tanterv szerint az idegen nyelvet negyedik osztályban tanulni kezdők csak a következö évfolyamon találkoznak az idegen nyelven az írásbeliséggel. Az idegen nyelven történő írás-olvasás bevezeté- 
se elöször a betük, aztán a szavak, majd a mondatok szintjén történik. A szerző minden szakasz leírását konkrét gyakorlatokkal illusztrálja.

Mint az korábban is említettük, az orális készségek, vagyis a hallás utáni megértés és a beszéd a nyelvtanulás domináns csatornái. A szóbeliség kitüntetett szerepe teszi a kiejtést, mint fejlesztendő kompetenciát elsődlegesen fontossá a 3-10 éves korban. Részletesen leírt gyakorlatok kapcsán tájékozódhat az olvasó a kiejtés tanításának módjairól. A tudatos kiejtéstanulást a ritmust és rímet előtérbe állító játékos, nem ritkán mozgással kísért feladatok kerülnek itt bemutatásra. A nyolcadik fejezet választ ad arra a kérdésre, miképpen rögzíthetők, memorizálhatók szavak abban az életszakaszban, amikor csupán a szóbeliségre lehet támaszkodni. Hangsúlyozni kell, hogy a kicsik másképp tanulnak szavakat, számukra a szavak értelmét a hozzájuk kapcsolódó szituációk, cselekvések segítenek megfejteni, megjegyezni. Ezért fontos az új lexikai egységek kontextusban való, vagy mozgással, mimikával kísért bemutatása, gyakoroltatása. A pedagógusnak az idegen nyelvủ szó felidézéséhez is segítséget kell nyújtania. Mindig érdemes böséges nyelvi inputot adni a tanulóknak, mert nem a hibátlan produkció a cél, hanem újabb és újabb alkalom biztosítása a nyelvvel való ismerkedésre, a sikerre. A tanulóban pozitív attitüdöt kell kialakítani az idegen nyelvü szavakkal kapcsolatban, melyben nagy segítséget nyújt a kép- és/vagy szókártyákkal való manipuláció. Erre is, és a szövegfeldolgozásra is találhatók konkrét gyakorlatok leírásai a könyvben.

A következö fejezetben választ kapunk arra a kérdésre, hogy a korai életkorban szükség van-e nyelvtantanításra? Elöre kell bocsátanunk, hogy ez egy olyan kérdés, melyről a szakirodalomban nem találunk egységes álláspontot. A szerző a kommunikatív nyelvtantanítás módszerét ajánlja, és be is mutatja konkrét gyakorlatokkal az olvasó számára.

A tizedik fejezetben világossá válik az olvasó számára, hogyan is valósítható meg a nyelvfejlesztés spontaneitása és tervszerüsége egyaránt. Ehhez képet kap a tantervfogalom változásairól, és a nyelvelsajátítás tervezésének alapelveiről, mint például a témaközpontú tervezés. A szerző ezt is gazdagon illusztrálja gyakorlati feladatokkal. Ebben a fejezetben egy öt órát felölelő, Mark Twain Koldus és királyfi címü ifjúsági regényének első két fejezetét feldolgozó részletes foglalkozástervezetét ismerheti meg az olvasó.

A tizenegyedik fejezet a klasszikus kérdéssel indít, lehetséges-e nyelvtanulás tankönyv nélkül, illetve használjon-e a pedagógus autentikus szövegeket vagy sem? Ennek a kérdésnek számos vetületét veti fel a szerző. Szükségszerú a tananyag fogalmának újradefiniálása. Ennek megfelelően a tankönyvek kiegészülnek munkafüzettel, audio- és videokazettával, ragasztható matricákkal, kép- és szókártyákkal, poszterekkel. Autentikus tananyagok kapnak helyet a tantervekben. Ezek a szempontok, és a tankönyvpiac liberalizációja által létrejött nagymértékben megnőtt kínálat, komoly kihívás elé állítja a pedagógusokat, s ebben a kérdésben a döntés ódiumát nekik kell felvállalni. 
Külön fejezet szól az eredményességről. Attól, hogy az értékelés nem osztályzással történik, még értékel a pedagógus; az óra minden fázisában, minden tevékenység után a tanár szóban és nem verbális eszközökkel értékel, buzdít, dicsér. Részletesen bemutatásra kerülnek, hogy mit és hogyan is kell értékelni az órán/foglalkozáson, a tudásszint mérésnek milyen módjai alkalmazhatók, mit is jelent ebben a korosztályban a hibajavítás fogalma, és hogyan kell a szülőket tájékoztatni gyermekük eredményeiröl.

A korábban elméleti szempontból felvetett témát - autentikus anyagok szerepe a korai nyelvelsajátításban - a szerző a tizenharmadik fejezetben hosszasan, konkrét példákkal alátámasztva dolgozza fel. Ehhez szükséges a gyermekirodalom fogalmának tisztázása, a „rövid müfajok” szerepének megismerése. E rövid bevezető után konkrét példákon keresztül ismerheti meg az olvasó a cselekvéssel kísért versmondás, a rímek, a nyelvtörők és találós kérdések feldolgozásának lehetséges módjait. A szerző összeállított egy algoritmust az irodalmi müvel való találkozás megszervezésére. Hangsúlyozza, hogy igazán akkor tesz mély benyomást az irodalom a gyermekre, ha nem csupán befogadó, de alkotó szerepet is vállalhat. Képet kaphat az olvasó gyermekirodalmi alkotásról a szavak és a mondatok szintjén. A gyermekirodalmi müvek is hozzájárulnak a korai nyelvelsajátítás egyik fő céljának a megvalósításához, a gyermeknek módot ad arra, hogy miközben megismeri ezeket, öszszehasonlítja a saját kulturális hátterével, és pozitív attitüdöt alakít ki a célnyelv kultúrája, és ezen keresztül, beszélöi iránt.

A korai nyelvfejlesztés e könyv szerint bizonyítottan hozzájárul a tanulói önállóság kialakításához. A szerző megismerteti olvasóját azon kognitív müveletekkel (párosítás, jóslás, azonosítás), melyek a tanulási stratégiák alapjait képezik. Ezután konkrét ötleteket kap az olvasó, hogy mely szituációkban mely stratégiát célszerü bevetni, s milyen rutintevékenységekkel fejleszthető az önálló tanulás készsége. A könyv végén a felhasznált irodalom, a szakkifejezések jegyzéke, és a témát érintő szakirodalmak annotált formában találhatók.

Kovács Judit: A gyermek és az idegen nyelv. Eötvös József Könyvkiadó, Budapest, 2009. 178 oldal 